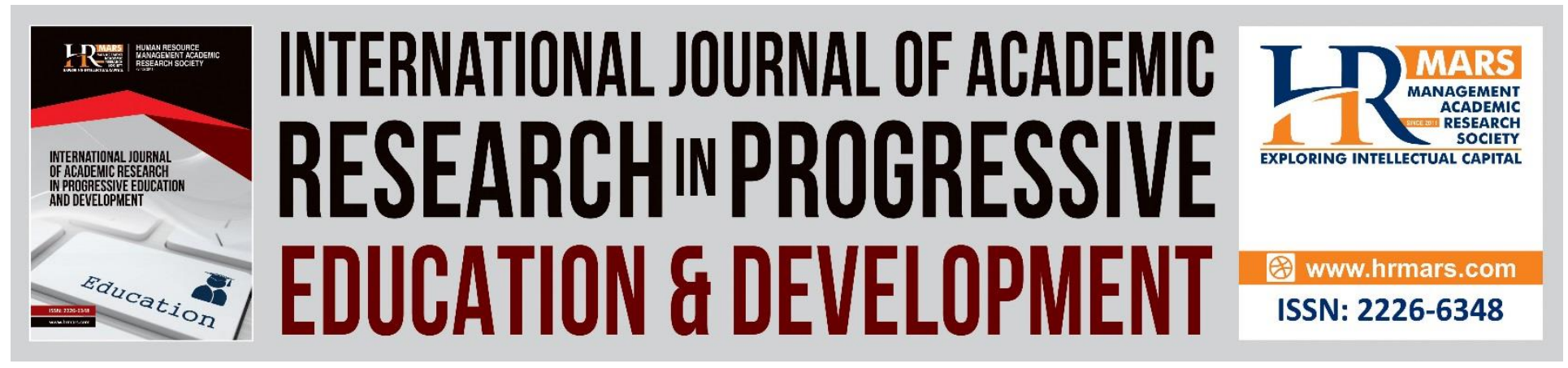

\title{
A Systematic Review of Augmented Reality in English Language Learning
}

Amalina Hasbi and Melor Md Yunus

To Link this Article: http://dx.doi.org/10.6007/IJARPED/v10-i2/9218

DOI:10.6007/IJARPED/v10-i2/9218

Received: 21 February 2021, Revised: 24 March 2021, Accepted: 16 April 2021

Published Online: 30 April 2021

In-Text Citation: (Hasbi \& Yunus, 2021)

To Cite this Article: Hasbi, A., \& Yunus, M. M. (2021). A Systematic Review of Augmented Reality in English Language Learning. International Journal of Academic Research in Progressive Education and Development, 10(2), 163-183.

Copyright: (C) 2021 The Author(s)

Published by Human Resource Management Academic Research Society (www.hrmars.com)

This article is published under the Creative Commons Attribution (CC BY 4.0) license. Anyone may reproduce, distribute, translate and create derivative works of this article (for both commercial and non-commercial purposes), subject to full attribution to the original publication and authors. The full terms of this license may be seen at: http://creativecommons.org/licences/by/4.0/legalcode

Vol. 10(2) 2021, Pg. 163 - 183

http://hrmars.com/index.php/pages/detail/IJARPED

JOURNAL HOMEPAGE

Full Terms \& Conditions of access and use can be found at http://hrmars.com/index.php/pages/detail/publication-ethics 


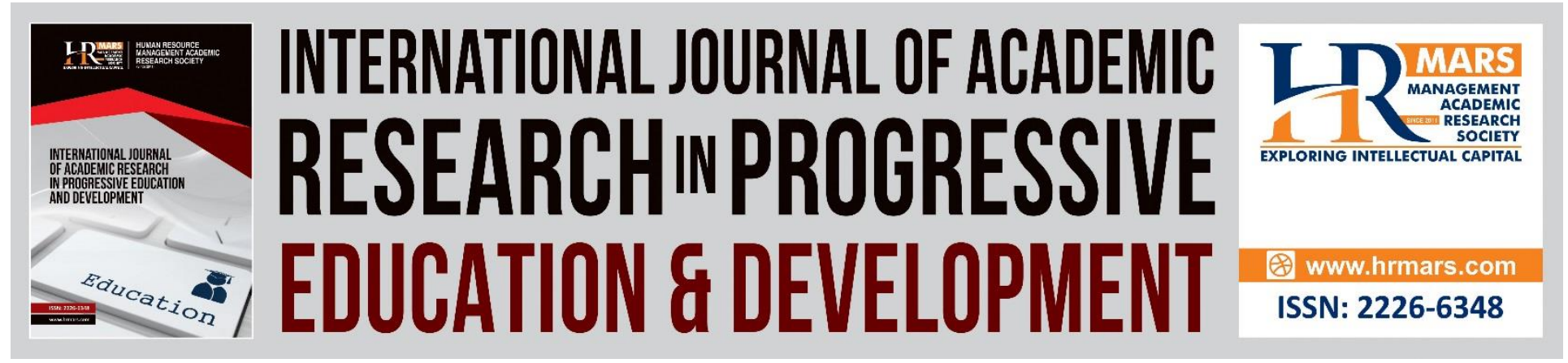

\title{
A Systematic Review of Augmented Reality in English Language Learning
}

\author{
Amalina Hasbi and Melor Md Yunus \\ Universiti Kebangsaan Malaysia \\ Email: melor@ukm.edu.my
}

\begin{abstract}
The use of technology in education has rapidly developed and various technological tools are implemented in the classroom. One of the technological tools which currently takes place in the interest of technology in education is augmented reality (AR). Hence, this study provides a systematic approach to explore how AR is practiced in English language learning (ELL), the benefits and limitations of using AR. This study employed comprehensive analysis and synthesis of 20 articles including peer-review journal articles and full-text articles within the period of 2016 to 2020 from three databases namely Google Scholar, ScienceDirect and Eric. Results of this study show that quantitative was mostly used in exploring the use of AR in ELL. This review also explores the features of AR mostly practiced in ELL and the positive impacts on ELL. Besides that, it analyses the constraints and limitations of using AR in teaching and learning. Overall, the results of this study show that all the studies agreed that AR can bring positive impacts towards ELL despite some limitations and constraints found in the integration of AR in learning.
\end{abstract}

Keywords: Augmented Reality, English, Language Learning, Systematic Review, Technology, Education

\section{Introduction}

The trend in the education system always changes rapidly to cater to various needs in this $21^{\text {st }}$ century, especially due to the advancement in technology. "This rapidity of advance in technologies demands a more proactive response from the educational sector than the more gradual societal evolution and subsequent response from educational institutions in earlier industrial evolutions" (Penprase, 2018). On that note, STEM education has been pointed out worldwide where young generations should be equipped with the knowledge in science, technology, engineering and mathematics so that they can compete globally. According to Freeman et.al. (2019), "science, technology, engineering and mathematics (STEM) education and research are increasingly recognised globally as fundamental to national development and productivity, economic competitiveness and societal wellbeing." The importance of STEM education is also aligned with the needs in the 4.0 industrial revolution. That said, the use of 
technology in education has also been highlighted as one of the ways to support STEM education. "In this part of $21^{\text {st }}$ century learning, the range of technologies available for use in language learning and teaching has become very diverse and the ways that they are being used in classrooms have become central to language practice" (Yunus, 2018).

Yunus (2018) also stated in her article that "technology is also having an impact on the development of pedagogy where the use of technology has enabled teachers to re-think what they are doing." Currently, learning is not necessarily revolved around the teacher solely, instead active learning and student-centered learning are encouraged towards developing the learner's knowledge. Prior to that, chalk and talk method as well as one-way learning is no longer seen as the sole practice in the teaching and learning process. To date, there are various ways teachers can carry out a lesson which is in line with the $21^{\text {st }}$ century learning, especially with the aid of technology. There is abundance of technologies that can be integrated in teaching and learning to help the teachers in creating an active and student-centered learning. Hashim (2018) also agreed that "the emergence technology such as cloud computing, Augmented Reality (AR) and 3D printing are paving way for the future of education."

Among the different types of technology, the use of AR has started to take place in the teaching and learning practice too. According to Danaei et.al. (2020), "AR has been used in educational settings and publication industry due to its potential for instructional usage." Many studies supported the use of AR in learning as it offers many advantages towards different aspects including pupils' performances, motivation as well as teacher's new teaching pedagogy. In terms of engagement, AR can engage pupils in learning due to its various features and the ability to connect both virtual and real world. Chen et.al. (2019) stated that "AR deepens learning interactions by imposing digital information on top of physical settings." "The attractiveness of $A R$ as a teaching-tool is its ability to deliver a blended learning experiences created from the mixing of the virtual and real environments or materials in the classroom" (Barrow et.al., 2019). This is inevitably beneficial in tandem to the fact the Ministry of Education is trying to reduce the gap between pupils from different background and different geographical settings. This is also pointed out in the latest education blueprint. In concern with the equity in education, the Ministry "aspires to halve the current urban-rural, socio-economic and gender achievement gaps by 2020" (Ministry of Education, 2013). Hence, by implementing AR in the classroom, teachers will be able to broaden pupils' horizon and enrich their experiences during the teaching and learning by bridging the real and virtual world experience.

Moreover, AR can also influence pupils' learning development. "It is gaining importance due to its positive effects on growth of children's memories, thinking skills and imaginations" (Safar et.al., 2017). This is also supported by Chen \& Chan (2019) in which "the mix of real content and multimedia content that AR system offers mediates children's sense of presence, immediacy and immersion." Lampe \& Hinske (2007) showed that "the ideal learning experience for a child comes from combining from physical experience, virtual content and the imagination of a child." Based on this statement, the use of AR in learning does fit the criteria of an ideal learning experience. That said, for an instance, 3D visual object is one of the features in AR can engage pupils in the learning and it can draw their attention compared to the traditional teaching method. When the teachers have successfully aroused their interest in learning, it indirectly will influence their participation and motivation in the teaching and learning. As has been previously reported in the 
study by Rafiq \& Hashim (2018), it can be summed up that augmented reality game can enhance the $21^{\text {st }}$ century skills, which are collaboration, communication, critical thinking and problem solving and at the same time, improves the English language of students. In short, the use of AR in learning can greatly assist and aid the process of acquiring new knowledge.

Nonetheless, there is still a need to explore how AR is practiced in English language learning, evaluate the benefits of implementing it in the classroom and figure out the limitations and constraints of using $A R$ in the language learning. Without taking these into account, it may contribute to the minimal gains of using AR during the teaching and learning process and less interest upon the use of AR by the educators. Apart from that, inevitably, by considering all these issues, it will provide sufficient information for the decision makers in analysing the latest change and need in the education system. Meanwhile, there are few systematic literature reviews which attempt to gear the focus towards the use of augmented reality as well. Pedaste et.al. (2020) conducted a systematic review of the potential of implementing augmented reality (AR) in inquiry-based learning. A literature review by Maas \& Hughes (2020) also provided "the first review of the existing literature consolidating research into the use of virtual, augmented and mixed reality technologies within K-12 educational environments." A systematic review by Sirakaya \& Sirakaya (2018) also aimed to identify the trends in the studies conducted on Education Augmented Reality (AR). These studies attempted to look the use of augmented reality in inquiry-based learning, within K-12 educational environments and in Educational AR. In spite of that, a study into the use of augmented reality which is geared towards language learning, specifically English language is still scarcely found compared to other disciplines. Hence, the aim of this review is:

a) to synthesise the findings of studies related to the use of AR in English language learning.

b) to analyse the benefits and constraints of using it.

Aligning with the past studies that are relevant and suitable to be analysed, the researcher has outlined three research questions:

a) How AR is practiced in English language learning?

b) What are the benefits of using AR in English language learning?

c) Is there any limitations and constraints of using AR in English language learning?

\section{Augmented Reality}

The emergence of technologies lately has paved a new and novel way for the educators to design the lesson in a more interesting yet purposeful way. The potential of using AR in language learning has garnered attention among different entities, especially the educators and the decision-makers. "Despite the ongoing debate on the use of AR in education, more and more AR products are becoming available on the market, and many of them are targeted at young children" (Chen \& Chan, 2019). According to Pedaste et.al. (2018), AR merges the real and the virtual worlds. This is also in line with the definition provided by Safar et. al. (2017), "AR is an advanced technology used in classrooms and provides real views as well as virtual views of realistic environments." "AR is a technology that augments the real physical world with computer-generated virtual 3D objects, which the users can interact with on the screen of devices like smartphone/tablet with a camera" (Lee et.al., 2019). Ho et.al. (2017) also agreed that "AR facilitates more effective demonstrations of spatial and temporal concepts, as well as the 
contextual relationships between real and virtual objects." In brief, it can be summed up that AR is the technological tool that can provide the users with the experiences in virtual world and real world simultaneously.by using various kinds of devices.

AR differs from other technological tools due to few features. "When the barcodes/markers are scanned, virtual images such as videos, 3D objects or other images combine with real-world data on the pointer" (Bursali \& Yilmaz, 2019). In tandem to that statement, the first characteristic that distinguish AR from other technological tools is, it bridges the virtual worlds with real worlds. The users are able to dive into a different world without leaving the real, current situation. Hence, it provides real and authentic situation to the users. At the same time, Virtual reality (VR) is also well-known as a tool that enable the users to immerse in virtual 3D environment. "While on the same continuum, AR differs from VR in that AR devices overlay digital content onto the physical world, whereas VR devices are completely closed off from the physical world, presenting a synthetic 3D virtual world" (Wang et.al., 2017). Second, it uses real-time instruction and third, it provides accurate 3D registration of virtual and real objects (Soo et.al., 2019). In other words, as mentioned previously, it allows the users to experience a different world through the 3D content and visualisation and it can occur simultaneously.

"With the rapid increase in learning technology, the applications of AR could be extended and could work with various learning devices such as tablet PCs and mobile phones" (Wang, 2017). It gives freedom to the users in selecting the devices to be used. AR implementations can be categorised into two, known as marker-based AR and markerless AR. As stated by Lee et.al. (2019), marker-based AR application relies on a reader (usually a camera of the mobile device) to read some type of image called marker (e.g., QR code) to produce the virtual 3D objects, which camera image is overlaid with. Marker-based AR is often used indoor as it does not need the users to rely on the location sensor to experience the content provided. Meanwhile, markerless AR does not require any marker image to create the virtual 3D objects; it relies on the location sensors of the mobile devices, e.g., GPS location, velocity metre, etc (Lee et.al., 2019). Hence, it is mostly used outdoors as the users are required to move around in order to access the content served in the AR tool.

\section{Method}

According to the Cochrane handbook, "a systematic review uses explicit, systematic methods that are selected with a view to minimizing bias, thus providing more reliable findings from which conclusions can be drawn and decisions made" (Munn et.al., 2018). In this study, a systematic analysis was carried out on searched articles from different databases including Google Scholar, ScienceDirect and Eric. The process of collecting articles from the databases was from March 2020 until June 2020. This systematic review aims to provide the guidelines and proper references in the area of augmented reality in English language learning. Hence, in this review, the researcher used five phases of systematic literature review as proposed by Khan (2003) as illustrated in Figure 1 below. 
Vol. 10, No. 2, 2021, E-ISSN: 2226-6348 @ 2021 HRMARS

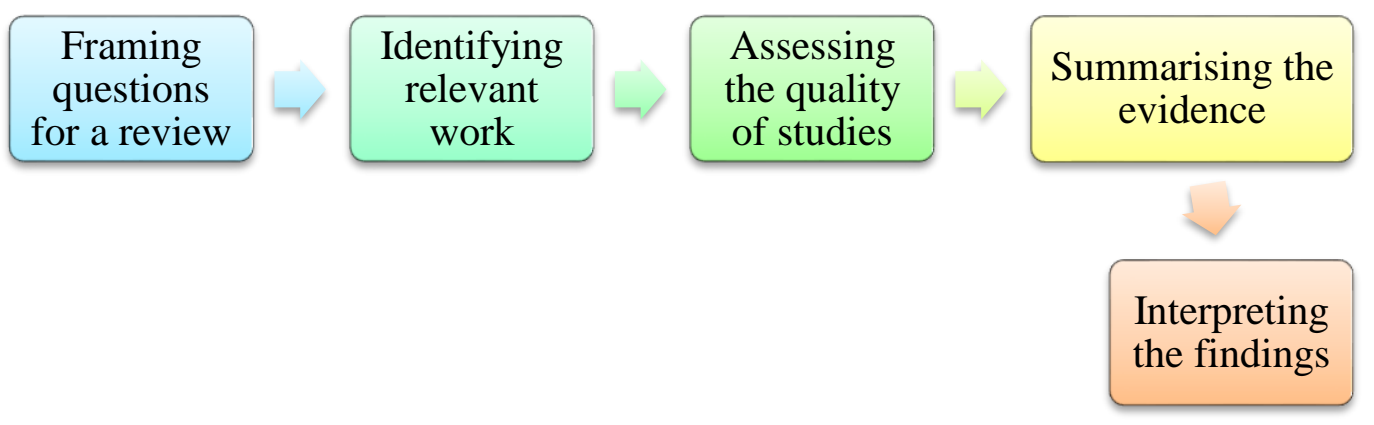

Figure 1: Phase of Systematic Literature Review

\section{Phase 1: Framing questions for a view}

"The use of digital technology by teachers from early years in primary education makes learning a more familiar experience for students today" (Spiteri \& Chang Rundgren, 2018). Due to the latest education trend, there are different types of technology-based learning that can be integrated in language learning, for an instance the use of augmented reality. In fact, language learning applications have been applying the use of AR (Godwin-Jones, 2016). Thus, this study intends to explore how AR is implemented in English language learning, the benefits and the limitations of using it in language learning, based on the articles published from 2016 to 2020. The research questions are:

a) How $A R$ is practiced in English language learning?

b) What are the benefits of using AR in English language learning?

c) Is there any limitations and constraints of using AR in English language learning?

\section{Phase 2: Identifying relevant work}

In the second stage, there were two processes involved. The process began with collecting all relevant articles in the initial research. Next, it is important to select the suitable articles based on the inclusion and exclusion criteria provided in the review. In the context of this review, the literature search focused only on the peer review journal articles and full-text articles. Thus, three databases namely Google Scholar, Eric and ScienceDirect were used in this review to ascertain comprehensive data collection. Apart from that, the period of literature search was limited to 2016 to 2020 to narrow down the search and to look for the most updated articles. At the same time, the keywords used in the initial search were 'augmented reality in language learning,' 'augmented reality in English learning,' 'augmented reality' and 'augmented reality in English language learning.' The different keywords were used as some databases resulted in a massive search result. Hence, the researcher narrowed down the search results by using different keywords in different databases.

\section{Phase 3: Assessing the quality of studies}

According to Siddaway et.al. (2019):

"The criteria for inclusion and exclusion in the systematic review are explicitly stated and consistently implemented such that the decision to include or exclude particular studies is clear 
Vol. 10, No. 2, 2021, E-ISSN: $2226-6348$ @ 2021 HRMARS

to readers and another researcher using the same criteria would likely make the same judgments."

Therefore, in assessing the quality of studies, the inclusion and exclusion criteria were defined. Furthermore, by stating the exclusion and inclusion criteria, it assisted the researcher to look for articles that meet the criteria in the study. Table 1 shows the inclusion criteria. Table 2 shows the exclusion criteria.

Table 1: Inclusion criteria

Inclusion criteria

augmented reality must be integrated in English language learning

uses research methodologies: qualitative, quantitative, mixed-method

sample or respondents from different levels of education

the studies access and evaluate augmented reality

teaching and learning using augmented reality

published between 2016 till 2020

Table 2: Exclusion criteria

\section{Exclusion criteria}

augmented reality was not integrated in English language learning

did not provide research methodologies: qualitative, quantitative, mixed-method

the studies did not access and evaluate augmented reality

teaching and learning did not use the augmented reality

the articles were not published between 2016 till 2020

In the context of this review, there were 6 inclusion criteria and 5 exclusion criteria stated to be used as a proper guideline in selecting the relevant articles. Only articles that met the inclusion criteria were selected in this review.

\section{Phase 4: Summarising the evidence}

Eric was used as the first database in this review. The search using the keywords 'augmented reality in language learning,' 'augmented reality in English learning' and 'augmented reality' in articles published from 2016 until 2020 resulted in massive results. By using the first keywords, it showed 21, 246 results and the second keywords resulted in 14, 485 results. The last keywords made it more convenient for the researcher as the results were narrowed down to 337 results in this database. However, only 24 results were related to language learning. By referring to the inclusion criteria, only 4 articles were selected as they met the criteria needed.

The second database used in this study was Google Scholar. To look for relevant articles published within the period of 2016 to 2020, the keywords used was 'augmented reality in language learning.' It resulted in 21 results. After sorting out the articles based on the inclusion criteria, 13 articles were selected.

The last database used in this review was ScienceDirect. To search for the relevant results, the keywords used was 'augmented reality in English language learning' and there were 520 articles found related to the keywords. Despite the 520 articles, only 7 articles are related the use of 
augmented in English language learning. Of 7 articles, only 3 articles were selected as they possessed all the inclusion criteria mentioned in Table 1.

\section{Phase 5: Interpreting the findings}

The next phase is to interpret the findings using content analysis. Quantitative, qualitative and mixed-method were used to perform the content analysis before categorical data can be tabulated or illustrated. Based on Figure 2, only 20 fitted the inclusion criteria stated in this review. Figure 2 illustrates the numbers of study based on methods used in the selected articles published within the period 2016 to 2020 and adhered to the inclusion criteria. Figure 2 shows that mixed method was the most frequently used method in previous studies compared to quantitative and qualitative method.

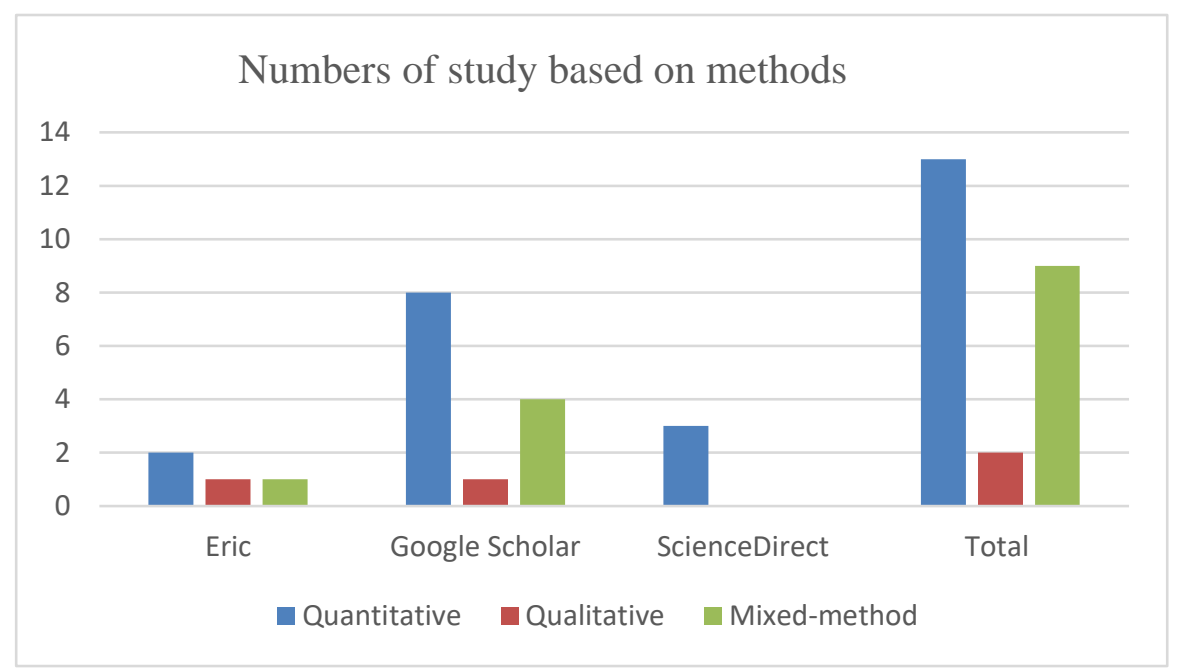

Figure 2: Numbers of study based on methods

After that, the different levels of learners participated in English language learning using augmented reality were also analysed. Figure 3 shows that augmented reality in English language learning was mostly used in primary school, followed by preschool and tertiary level. The least number of learners participated in English language learning using AR is in secondary school. 
INTERNATIONAL JOURNAL OF ACADEMIC RESEARCH IN PROGRESSIVE EDUCATION AND DEVELOPMENT

Vol. 10, No. 2, 2021, E-ISSN: 2226-6348 @ 2021 HRMARS

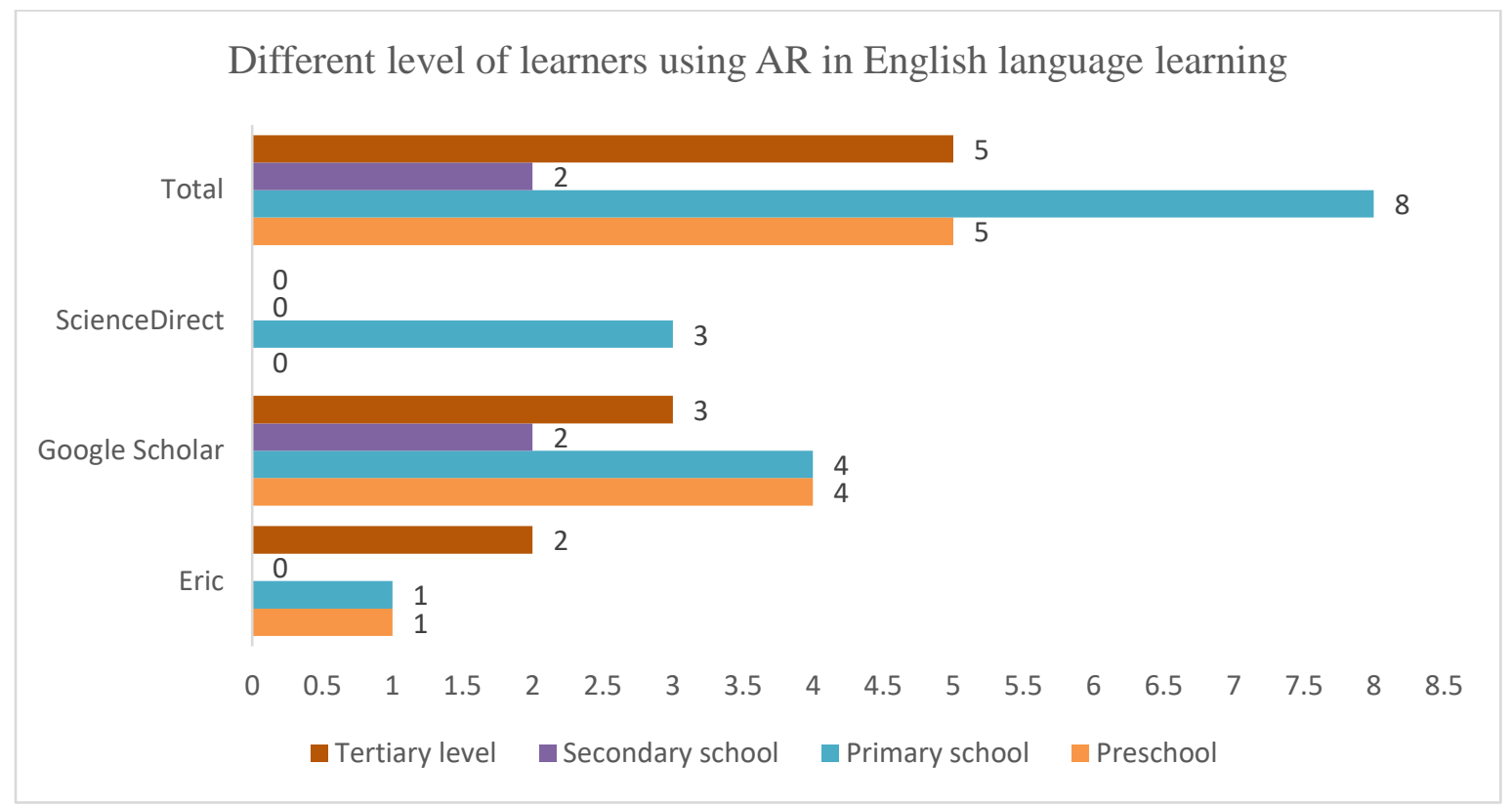

Figure 3: Different level of learners using AR in English language learning

\section{Results}

How augmented reality is practiced in English language learning?

The different features of AR implemented in English language learning were divided into the location, marker-based AR and markerless AR. The findings in each study is represented in Table 3. Further details on the participants and types of instruments used in each study are presented in Table 4. 
INTERNATIONAL JOURNAL OF ACADEMIC RESEARCH IN PROGRESSIVE EDUCATION AND DEVELOPMENT

Vol. 10, No. 2, 2021, E-ISSN: 2226-6348 @ 2021 HRMARS

Table 3: Characteristics of augmented reality used in language learning

\begin{tabular}{|c|c|c|c|c|}
\hline \multirow[t]{2}{*}{ No } & \multirow[t]{2}{*}{ Author } & \multicolumn{3}{|c|}{ Features of augmented reality } \\
\hline & & Location & Marker-based & Markerless \\
\hline 1 & Hsu (2017) & Indoor & / & \\
\hline 2 & $\begin{array}{l}\text { Che Samihah et.al. } \\
\qquad(2019)\end{array}$ & Indoor & / & \\
\hline 3 & Richardson et.al. (2016) & Outdoor & & / \\
\hline 4 & Yaacob et.al. (2019) & Indoor & / & \\
\hline 5 & Solak \& Cakir (2016) & Indoor & / & \\
\hline 6 & Yeh \& Tseng (2020) & Outdoor & & / \\
\hline 7 & Chen (2018) & Indoor & / & \\
\hline 8 & Taskiran (2018) & Indoor & / & \\
\hline 9 & Redondo et.al. (2019) & Indoor & / & \\
\hline 10 & Wang \& Khambari (2020) & $\begin{array}{c}\text { indoor and } \\
\text { outdoor }\end{array}$ & / & / \\
\hline 11 & $\begin{array}{l}\text { Tobar-Munoz et.al. } \\
\qquad(2017)\end{array}$ & Indoor & / & \\
\hline 12 & Danaei et.al. (2020) & Indoor & / & \\
\hline 13 & $\begin{array}{c}\text { Sadikin \& Martyani } \\
(2020)\end{array}$ & indoor & / & \\
\hline 14 & Martinez et.al. (2017) & indoor & / & \\
\hline 15 & Al-Asheeri (2017) & Indoor & / & \\
\hline 16 & Safar et.al. (2017) & indoor & / & \\
\hline 17 & Chen \& Chan (2019) & indoor & / & \\
\hline 18 & Soo et.al. (2019) & indoor & / & \\
\hline 19 & Lee et.al. (2019) & $\begin{array}{c}\text { indoor and } \\
\text { outdoor }\end{array}$ & / & / \\
\hline 20 & Tsai (2020) & indoor & / & \\
\hline
\end{tabular}

Table 4: summarisation of methodology of using augmented reality in language learning

\begin{tabular}{|c|c|c|c|}
\hline No & Author & Research participant & Research instrument \\
\hline 1 & Hsu (2017) & $\begin{array}{c}38 \text { third graders, average } \\
\text { age was nine }\end{array}$ & $\begin{array}{c}\text { pre- test, post - test, } \\
\text { questionnaires }\end{array}$ \\
\hline 2 & $\begin{array}{l}\text { Che Samihah et.al. } \\
\qquad(2019)\end{array}$ & $\begin{array}{l}120 \text { Malaysian preschool } \\
\text { children aged between } 4 \text { to } \\
6 \text { years old }\end{array}$ & $\begin{array}{c}\text { pre-test and post- test, task } \\
\text { completion time, } \\
\text { questionnaires }\end{array}$ \\
\hline 3 & Richardson et.al. (2016) & $\begin{array}{c}78 \text { students from four } \\
\text { separate advanced level } \\
\text { English courses at Karlsruhe } \\
\text { Institute of Technology (19- } \\
25 \text { years old) }\end{array}$ & $\begin{array}{l}\text { observation, documents, } \\
\text { learners' feedback, } \\
\text { reflective mission reports }\end{array}$ \\
\hline 4 & Yaacob et.al. (2019) & $\begin{array}{c}5 \text { boys and } 5 \text { girls from Year } \\
1\end{array}$ & $\begin{array}{l}\text { pre-test and post-test, } \\
\text { semi-structured interview }\end{array}$ \\
\hline
\end{tabular}


Vol. 10, No. 2, 2021, E-ISSN: 2226-6348 @ 2021 HRMARS

$5 \quad$ Solak \& Cakir (2016)

$6 \quad$ Yeh \& Tseng (2020)

7

Chen (2018)

8 Taskiran (2018)

9 Redondo et.al. (2019)

10 Wang \& Khambari

(2020)

11 Tobar-Munoz et.al. (2017)

12 Danaei et.al. (2020)

13 Sadikin \& Martyani (2020)

14 Martinez et.al. (2017)

15 Al-Asheeri (2017)

16 Safar et.al (2017)

17 Chen \& Chan (2019)

18 Soo et.al. (2019)

19 Lee et.al. (2019)

20 Tsai (2020)
Age ranges from 10-11, 30 in experimental group, 31 in control group

52 EFL students

36 students in grade 1 of a primary school in Thailand 83 Turkish students were chosen (convenience sampling), ages varied bwteen 18 and 24

52 experimental group, 50 control group childhood education pupils 50 vocational college students

52 third through sixth graders from a southwestern Colombian school

34 children aged 7 to 9 from 5 children libraries in Tehran

30 primary students at second grade in Padalarang 150 children of five years of age

59 elementary students 42 pre-schoolers (21 in experimental group, 21 in control group)

98 children aged between 5 and 6 years and 4 teachers 10 students and 7 lecturers from UTM Negeri Sembilan 30 randomly participants 60 elementary students pre- test, post-test

pre-test and post-test, students' reflection essays pre-test and post-test, a questionnaire questionnaires

pre-test and post-test, questionnaires

semi-structured interview, questionnaire questionnaire, literal comprehension and inferential comprehension questions, video recording pre-test and post-test, comprehension scores

pre-test and post-test evaluation result

pre-test and post-test observation card, achievement test

pre-test and post-test, interview only for teachers interview and discussion

preliminary evaluations pre-test and post-test

\section{What are the benefits of using AR in English language learning?}

Based on the selected studies, it was reported that the use of AR brings positive impact towards English language learning. Previous studies revealed that AR was implemented for different language skills including vocabulary, reading skill, speaking skills, writing skill, phonics approach as well as the teaching and learning of English in general. Table 5 shows the discussion of each 
Vol. 10, No. 2, 2021, E-ISSN: 2226-6348 @ 2021 HRMARS

author on the use of AR in English language learning. Figure 4 demonstrates the different language skills employed in each study.

Table 5: Key findings of augmented reality in language learning

\begin{tabular}{|c|c|c|c|}
\hline No & Author & Key finding & Focus \\
\hline 1 & Hsu (2017) & $\begin{array}{l}\text { "The mean score in the post- test of the students who } \\
\text { learned with the task-based AR educational games } \\
\text { was } 79.71 \text { compared with } 77.75 \text { for those who } \\
\text { learned with the self-directed AR educational } \\
\text { games." }\end{array}$ & learning styles \\
\hline 2 & $\begin{array}{l}\text { Che } \\
\text { Samihah } \\
\text { et.al. } \\
\text { (2019) }\end{array}$ & $\begin{array}{l}\text { "The Gain shapes for the AR speech group }(M d n=3) \text { is } \\
\text { higher compared to the non-AR non-speech group } \\
\text { (Mdn=2). AR is more effective than traditional } \\
\text { method." }\end{array}$ & $\begin{array}{l}\text { speech } \\
\text { recognition } \\
\text { towards English } \\
\text { learning }\end{array}$ \\
\hline 3 & $\begin{array}{l}\text { Richardson } \\
\text { et.al. } \\
\text { (2016) }\end{array}$ & $\begin{array}{l}\text { "Observational field notes made frequent mention of } \\
\text { signs that participants were engaged in finding the } \\
\text { trigger images and recording the language tasks. " }\end{array}$ & $\begin{array}{l}\text { English skills, } \\
\text { language } \\
\text { learning }\end{array}$ \\
\hline 4 & $\begin{array}{l}\text { Yaacob } \\
\text { et.al. } \\
\text { (2019) }\end{array}$ & $\begin{array}{l}\text { The results indicated that all } 10 \text { students' vocabulary } \\
\text { scores improved after being introduced to AR } \\
\text { flashcards. }\end{array}$ & $\begin{array}{l}\text { vocabulary } \\
\text { learning }\end{array}$ \\
\hline 5 & $\begin{array}{l}\text { Solak \& } \\
\text { Cakir } \\
(2016)\end{array}$ & $\begin{array}{l}\text { "According to result of retention test, the mean of the } \\
\text { participants in the experimental group }(\tilde{X}=71.67) \text { was } \\
\text { higher than the mean of the control group }(\tilde{X}=51.15) \text {. } \\
\text { This proved that the activities designed with AR } \\
\text { technology led to longer storage in long term } \\
\text { memory." }\end{array}$ & ulary \\
\hline 6 & $\begin{array}{l}\text { Yeh } \\
\text { Tseng } \\
\text { (2020) }\end{array}$ & $\begin{array}{l}\text { "These findings may encourage EFL teachers to } \\
\text { engage their students in AR content making to } \\
\text { develop their multimodal literacy" }\end{array}$ & En \\
\hline 7 & $\begin{array}{l}\text { Chen } \\
(2018)\end{array}$ & $\begin{array}{l}\text { "It was found that students had significantly better } \\
\text { phonics learning performance after using the } \\
\text { application ( } t=-12.44, p=0.00 \text { ), the application could } \\
\text { help them to improve their phonics learning } \\
\text { performance." }\end{array}$ & $\begin{array}{l}\text { phonics } \\
\text { approach }\end{array}$ \\
\hline 8 & $\begin{array}{l}\text { Taskiran } \\
(2018)\end{array}$ & $\begin{array}{l}\text { The findings revealed that almost all participants } \\
\text { enjoyed the use of learning materials enriched by AR. }\end{array}$ & $\begin{array}{l}\text { language } \\
\text { motivation }\end{array}$ \\
\hline 9 & $\begin{array}{l}\text { Redondo } \\
\text { et.al. } \\
\text { (2019) }\end{array}$ & $\begin{array}{l}\text { The results show a significant improvement in } \\
\text { motivation, learning and socio-affective relationships } \\
\text { in the experimental group. }\end{array}$ & $\begin{array}{l}\text { language } \\
\text { learning }\end{array}$ \\
\hline 10 & $\begin{array}{l}\text { Wang \& } \\
\text { Khambari } \\
(2020)\end{array}$ & $\begin{array}{l}\text { It showed that apart from the reasons of creating new } \\
\text { way of interaction and enhancing learning } \\
\text { motivation, the change of teacher's role eliminated }\end{array}$ & $\begin{array}{l}\text { English sentence } \\
\text { learning, } \\
\text { collaborative } \\
\text { learning }\end{array}$ \\
\hline
\end{tabular}


the pressure from traditional teacher's role in China which promoted the effect of English learning.

11 Tobar- "Those using the game tended to outperform the Munoz children not using it and children playing with the et.al. game feel it is a more pleasurable and enjoyable (2017) activity than the sole act of reading."

12 Danaei et.al. (2020)

13 Sadikin \& In summary, learning English vocabulary through AR Martyani (2020)

14 Martinez et.al. (2017)

15 Al-Asheeri (2017)

"The results showed a significant difference between the control and experimental groups in terms of overall reading comprehension."

could improve students' vocabulary mastery. It made young learners more engaged and excited to learn English vocabulary.

"The result is that $73.7 \%$ of the students have affirmed that they are very happy with the methodology and activities."

The data analysis revealed an improvement of students' performance in learning English in the experimental group than their peers in the controlled group.

16 Safar et.al The average of the experimental group was 27.57 and (2017) that of the control group was 15.43 .

17 Chen \& The results showed that both AR and traditional Chan flashcards could significantly improve children's (2019) vocabulary learning and that there was no significant difference in effectiveness between $A R$ and traditional flashcards.

18 Soo et.al. All the students perceived that they have never seen (2019) this technology before (100\%).

19 Lee et.al. Most of the respondents partially agree that (2019) kindergarten students can learn English vocabulary effectively using the app.

20 Tsai (2020) 'AR had a significant effect on students' English vocabulary learning with various levels of low, intermediate and high groups, as shown by the $\mathrm{F}$ value $(2.27)=22.23, p<.00001$." reading comprehension, performance and motivation reading comprehension vocabulary learning

English learning

English learning

English alphabet lesson vocabulary learning writing skill vocabulary learning vocabulary learning 


\section{Different focus in the studies}

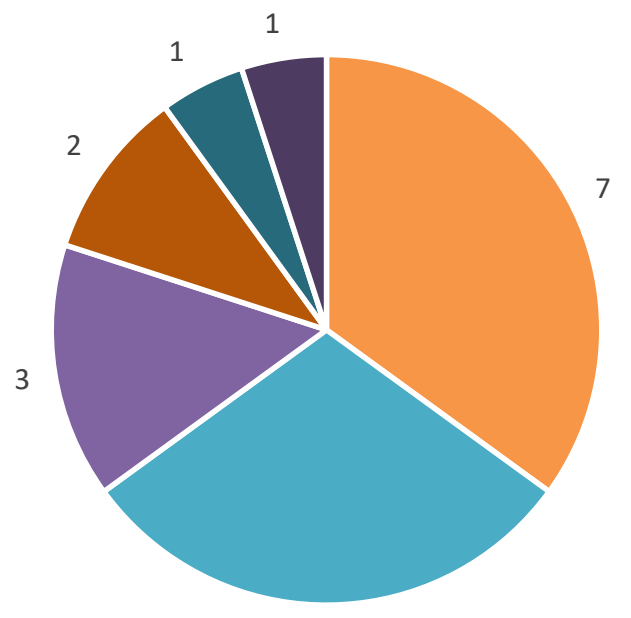

6

- General " Vocabulary - Reading skill - Writing skill - Speaking skill - Phonics

Figure 4: Different focus in the studies of AR in English language learning

Is there any limitation or constraint in using augmented reality in English language learning?

Despite positive impacts towards English language learning, the limitations or constraints of using AR were reported in each study. Hence, Table 6 shows the discussion of limitations and suggestions by each author.

Table 6: limitations of using AR in English language learning

\begin{tabular}{|c|c|c|c|c|}
\hline No & \multicolumn{2}{|c|}{ Author } & Limitations and suggestions & Keywords \\
\hline 1 & \multicolumn{2}{|l|}{ Hsu (2017) } & $\begin{array}{l}\text { The learning targets were all objects and may } \\
\text { be unsuitable for generalisation to older } \\
\text { students. } 2\end{array}$ & $\begin{array}{l}\text { limited content, } \\
\text { limitation in } \\
\text { generalisation }\end{array}$ \\
\hline 2 & $\begin{array}{l}\text { Che Sar } \\
\text { et.al. (2019) }\end{array}$ & $\begin{array}{l}\text { mihah } \\
\text { ) }\end{array}$ & $\begin{array}{l}\text { Teachers need to consider ensuring close } \\
\text { guidance, feasibility of using the Kinect sensor } \\
\text { for audio capturing, limitation of generalisation }\end{array}$ & $\begin{array}{l}\text { technical issues, } \\
\text { limitation in } \\
\text { generalisation }\end{array}$ \\
\hline 3 & $\begin{array}{l}\text { Richardson } \\
\text { (2016) }\end{array}$ & et.al. & $\begin{array}{l}\text { The trigger images disappear shortly before } \\
\text { gameplay commences, more explicit } \\
\text { instructions to be given to the participants }\end{array}$ & technical issues \\
\hline 4 & $\begin{array}{l}\text { Yaacob } \\
\text { (2019) }\end{array}$ & et.al. & $\begin{array}{l}\text { Teacher may also consider the use of this } \\
\text { application in teaching other language skills. }\end{array}$ & tent \\
\hline 5 & $\begin{array}{l}\text { Solak \& } \\
(2016)\end{array}$ & Cakir & $\begin{array}{l}\text { Only reflect achievement of target age group, } \\
\text { the findings can be supported through } \\
\text { interviews and observations, cognitive } \\
\text { processes are not investigated }\end{array}$ & $\begin{array}{l}\text { limitation in } \\
\text { generalisation }\end{array}$ \\
\hline
\end{tabular}


Vol. 10, No. 2, 2021, E-ISSN: 2226-6348 @ 2021 HRMARS

6 Yeh \& Tseng It is suggested that future studies may compare technical issue (2020) different AR development for educators in terms of their affordances.

7 Chen (2018) Limited generalisation, the usability of application, the quality of devices should be in high performance to avoid learning distraction

limitation in generalisation, technical issue

8 Taskiran (2018)

9 Redondo et.al. A longitudinal study of young children older (2019) than the preschool stage is suggested

limitation in generalisation

10 Wang

\& The model can be expanded, the group size Khambari (2020) was too big during the implementation, needs better learning place and infrastructure limitation in generalisation, technical issue

11 Tobar-Munoz Students argued with each other about the et.al. (2017) game and the problem to solve, needed several social skills, gaming and reading takes more time

12 Danaei

et.al. No difference in recalling literal and inferential (2020) questions when reading AR and non-AR book. Some AR aspects might have influenced the reading comprehension.

13 Sadikin \& -

Martyani (2020)

14 Martinez et.al. A large number of students, the considerable (2017) resources needed, difficulties for image recognition

15 Al-Asheeri (2017) Reconsider the current used learning materials limited content and substitute with content using AR

16 Safar et.al (2017) Time limitation, technical limitations, the scarcity of educational studies on this topic in the state of Kuwait

17 Chen \& Chan The testing may not be suitable for (2019) kindergarten children, children's background and geographical locations may influence the results. technical issues

technical issues

technical issues The study could be could be conducted at a limitation in wider scale with more measuring instruments. generalisation

19 Lee et.al. (2019) The current prototype does not provide limited content enough English vocabulary learning materials.

20 Tsai (2020) 
Vol. 10, No. 2, 2021, E-ISSN: 2226-6348 @ 2021 HRMARS

\section{Discussion}

\section{How AR is practiced in English language learning?}

In terms of how AR is practiced in English language learning, the findings look into the level of learners involved in the studies, the location of AR implementation and either they are markerbased or markerless. The results of this study show that AR was mostly used in primary school with $40 \%$ of level of learners participated in English language learning by using this technological tool (Hsu, 2017; Yaacob, 2019; Solak \& Cakir, 2016; Chen , 2018; Tobar-Munoz et.al., 2017; Danaei et.al., 2020; Sadikin \& Martyani., 2020; Martinez et.al., 2017;). The level of learners participated in ELL using AR at the tertiary level and preschool show the same percentage of $50 \%$. This reveal that the interest of using AR has started among the educators in preschool (Lee et.al., 2019; Chen \& Chan. 2019; Safar et.al., 2016; Redondo, 2019; Che Samihah et.al., 2019) and the use of AR is also relevant among university learners (Soo et. al., 2019; Wang \& Khambari, 2020; Taskiran, 2018; Yeh \& Tseng, 2020; Richardson et.al., 2016). In spite of the high percentage of AR implementation in three different levels, it was still at a low number in secondary school (Tsai, 2020; Al-Asheeri, 2017).

Apart from that, the results of this study also demonstrate that AR was used at different location and by using different types of feature known as marker-based AR and markerless AR. Of 20 studies reviewed, 16 studies integrated the use of marker-based AR while, 2 studies, conversely used markerless AR. At the same time, there are 2 studies by (Lee et.al., 2019; Wang \& Khambari, 2020) which incorporated both features of marker-based and markerless AR. Due to that feature of $A R$, the location is also highly influenced, either it was carried out indoor or vice-versa. As mentioned above, marker-based AR is mostly used indoor meanwhile, markerless AR is often used outdoor. Most of the studies carried out AR indoor (Hsu, 2017; Che Samihah et.al., 2019; Yaacob et.al., 2019; Solak \& Cakir, 2016; Chen , 2018; Taskiran, 2018; Redondo et.al., 2019; TobarMunoz et.al., 2018; Danaei et.al., 2020; Sadikin \& Martyani, 2020; Martinez et.al., 2017; AlAsheeri, 2017; Safar et.al., 2017; Chen \& Chan, 2019; Soo et.al., 2019; Tsai, 2020) compared to outdoor (Richardson et.al., 2016; Yeh \& Tseng, 2020). At the same time, the studies also showed that AR can be used simultaneously indoor and outdoor (Lee et.al., 2019; Wang \& Khambari, 2020).

\section{The benefits of using AR in English Language Learning}

In concern with the positive responses of using AR in English language learning, the results revealed that the implementation of this technological tool has brought positive impacts towards the teaching and learning of English. The focus in each study has been analysed and categorised into several categories based on the findings. As mentioned earlier, Figure 4 shows the different categories based on the findings namely vocabulary, writing skill, reading skill, speaking skill, phonics lesson and English learning in general. This review found evidence that can relate the use of AR has significantly improved English language learning, especially for the students (Hsu, 2017; Richardson et.al., 2016; Yeh \& Tseng, 2020; Taskiran, 2018; Redondo et.al., 2019; Martinez et.al., 2017; Al-Asheeri, 2017). First, the use of AR affected the learner's motivation in the English lessons and hence, improved their learning performance (Taskiran, 2018; Redondo et.al., 2019; Martinez et.al., 2017). This is also supported by the fact that AR was able to engage the learners, 
for instances in finding the trigger images and recording the language tasks (Richardson et.al., 2016; Yeh \& Tseng, 2020).

Besides that, vocabulary learning was positively influenced by the implementation of AR. The results show that AR could significantly improve the vocabulary learning (Yaacob et.al., 2019; Solak \& Cakir, 2016; Sadikin \& Martyani, 2020; Chen \& Chan, 2019; Lee et.al., 2019; Tsai, 2020). Solak \& Cakir (2016) in their study proved that the activities designed with AR led to stronger storage in long term memory. This is also supported by Cheng (2020) in which "AR has a significant effect on students' English vocabulary learning with various levels of low, intermediate and high groups."

The results of this review also found clear support for the advantages in the learner's reading skill as the result of using AR. Tobar-Munoz et.al., (2017) stated that "those using the game tended to outperform the children not using it and children playing with the game feel it is a more pleasurable and enjoyable activity the sole act of learning." Their findings were also similar to Danaei et.al., (2020); Safar et.al., (2017) in which the results showed a better performance of children using AR compared to those who were not exposed to the use of AR. From this review, it can also be reported that the use of AR was also employed in teaching other English language skills such as writing skill (Wang \& Khambari, 2020; Soo et.al., 2019), speaking skill (Che Samihah et.al., 2019) and phonics approach (Chen, 2018).

\section{The Limitations and Constraints of using AR in English Language Learning}

Although the use of AR is widely used in English language learning nowadays, a major source of limitation was also found due to the technical issues. A similar pattern of issues was obtained in the studies by (Che Samihah et. al., 2019; Richardson et.al., 2016; Yeh \& Tseng, 2020; Chen, 2018; Wang \& Khambari, 2020; Tobar-Munoz et.al., 2017; Danaei et.al., 2020; Martinez et.al., 2017). In the study by Richardson et.al. (2016), the trigger images disappeared shortly before gameplay continues. This is one of the main constraints of using technological tool in teaching and learning. Hence, Chen. (2018) mentioned that the quality of device can also influence the use of AR. Without taking this issue into account, the learning process will be distracted.

Another constraint in employing AR involves the issue of limitation in generalisation (Hsu, 2017; Che Samihah et.al., 2019; Solak \& Cakir, 2016; Chen, 2018; Redondo et. al., 2019; Wang \& Khambari, 2020; Safar et.al., 2017; Chen \& Chan, 2019; Soo et.al., 2019). For an instance, in the study by Solak \& Cakir (2016), their study can only reflect achievement of the target age group. Both studies by Wang \& Khambari (2020); Soo et.al. (2019) suggested that the study could be conducted at a wider scale with more measuring instruments. Nonetheless, only few studies revealed an issue concerning the limitation of content presented through AR (Hsu, 2017; Yaacob et.al., 2019; Al-Asheeri, 2017; Safar et.al., 2017; Lee et.al., 2019).

\section{Conclusion}

This review has enabled the researcher to answer all three research questions. First, in the context of implementing AR in English language learning, the results revealed that $A R$ has been applied in English language learning at different levels, including preschool, primary school, secondary school and in the tertiary level. This shows that different levels in the education system have taken some interest in the use of AR. In addition, although AR can be used both indoor or 
outdoor, it can be seen that AR was mostly used indoor compared to outdoor. In relation to that, marker-based AR showed a higher percentage of being used in English language learning. For some reason, it can be concluded that, the location of AR was used relies heavily on the feature of $A R$, either it is marker-based AR or markerless AR.

Second, it is also important to note that the results of this review are able to cast a new light on the use of technological tool in English language learning. As indicated in the findings, AR has elevated English language learning in various aspects. Generally, in the teaching and learning of English, AR has improved pupils' performance as it is related to learning motivation and learning engagement. Despite that, superior results are also seen for the positive impacts towards vocabulary learning as the studies mostly explored the effects of AR in pupils' vocabulary learning. However, the results have also assisted the researcher in figuring out that the use of AR gearing towards other language skills are still at minimum level. This would be an interesting and new point of view to study further especially in the context of AR in English language learning. Nevertheless, this review has also explored into the limitations and constraints that may hinder the educators from implementing AR in English language learning. It is mentioned in most of the studies that technical issues in using AR can affect the process of teaching and learning. This indicates that although the technological tool can positively improve English language learning, it is also inevitable for us to deal with the technical issues as any technological tools still has their own weaknesses and limitations. Regardless of that, only five studies revealed the issues related to limited content. This shows that the English language content is still continuously developed and the content is relevant regardless of different levels of learner.

At the same time, in concern with the limitation of generalisation, most of the studies found out that the results cannot be generalised as the results can only indicate specific learner's age. This defines that their findings may be relevant to a specific target of learners. Therefore, more studies can be carried out to deal with this issue as the development of AR is rapidly developed and there might be more interest regarding the use of $A R$ in language learning in the future.

\section{References}

Barrow, J., Forker, C., Sands, A., O'Hare, D., \& Hurst, W. (2019). Augmented Reality for Enhancing Life Science Education. Proceedings of The Fourth International Conference on Applications and Systems of Visual Paradigms, Rome: Italy.

Bursali, H., \& Yilmaz, R. M. (2019). Effect of Augmented Reality Applications on Secondary School Students' Reading Comprehension and Learning Permanency. Computers in Human Behavior, doi:10.1016/j.chb.2019.01.035

Che Dalim, C. S., Sunar, M. S., Dey, A., \& Billinghurst, M. (2020). Using augmented reality with speech input for non-native children's language learning. International Journal of Human-Computer Studies, 134, 44-64. https://doi.org/10.1016/j.ijhcs.2019.10.002

Chen, I. (2018). The Application of Augmented Reality in English Phonics Learning Performance of ESL Young Learners. 2018 1st International Cognitive Cities Conference (IC3), 255-259.

Chen, M.-P., Wang, L.-C., Zou, D., Lin, S.-Y., Xie, H., \& Tsai, C.-C. (2020). Effects of captions and English proficiency on learning effectiveness, motivation and attitude in augmented-reality-enhanced theme-based contextualized EFL learning. Computer 
INTERNATIONAL JOURNAL OF ACADEMIC RESEARCH IN PROGRESSIVE EDUCATION AND

DEVELOPMENT

Vol. 10, No. 2, 2021, E-ISSN: 2226-6348 @ 2021 HRMARS

Assisted Language Learning, 1-31. doi:10.1080/09588221.2019.1704787

Chen, R. W., \& Chan, K. K. (2019). Using Augmented Reality Flashcards to Learn Vocabulary in Early Childhood Education. Journal of Educational Computing Research, 57(7), 18121831. https://doi.org/10.1177/0735633119854028

Danaei, D., Jamali, H. R., Mansourian, Y., \& Rastegarpour, H. (2020). Comparing reading comprehension between children reading augmented reality and print storybooks. Computers \& Education, 103900. doi:10.1016/j.compedu.2020.103900

Hashim, H. (2018). Application of technology in the digital era education. International Journal of Research in Counseling and Education, 2(1), 1-5.

Hsu, T.-C. (2017). Effects of gender and different augmented reality learning systems on English vocabulary learning of elementary school students. Universal Access in the Information Society. doi:10.1007/s10209-017-0593-1

Hsu, T.-C. (2017). Learning English with Augmented Reality: Do learning styles matter? Computers \& Education, 106, 137-149. doi:10.1016/j.compedu.2016.12.007

Godwin-Jones, R. (2016). Augmented reality and language learning: From annotated vocabulary to place-based mobile games. Language Learning \& Technology 20(3), 9-19. Retrieved from http://lt.msu.edu/issues/october2016/emerging.pdf

Khan, K. S., Kunz, R., Kleijnen, J., \& Antes, G. (2003). Five steps to conducting a systematic review. JRSM, 96(3), 118-121. doi:10.1258/jrsm.96.3.118

Lampe, M., \& Hinke, S. (2007). Integrating interactive learning experiences into augmented toy environments. Proceedings of the Pervasive Learning Workshop at the Pervasive Conference (pp. 1-9).

Lee, L.-K., Chau, C.-P., Tsoi, K.-N., Yang, N. L., \& Wu, N.-I. (2019). A Mobile Game for Learning English Vocabulary with Augmented Reality Block Builder. Technology in Education: Pedagogical Innovations, 116-128. doi:10.1007/978-981-13-9895-7_11

Lee, L. K., Chau, C. H., Chau, C. H., Ng, C. T., Hu, J. H., Wong, C. Y., \& Wu, N. I. (2019). Improving the experience of teaching and learning kindergarten-level English vocabulary using augmented reality. International Journal of Innovation and Learning, 25(2), 110. doi:10.1504/ijil.2019.097661

Rafiq, M. K. R., \& Hashim, H. (2018). Augmented Reality Game (ARG), 21st century skills and ESL classroom. Journal of Educational and Learning Studies, 1(1), 29-34. https://doi.org/10.32698/0232

Maas, M. J., \& Hughes, J. M. (2020). Virtual, augmented and mixed reality in $\mathrm{K}-12$ education: a review of the literature. Technology, Pedagogy and Education, 1-19. doi:10.1080/1475939x.2020.1737210

Martinez, A. A., Benito, J. R., \& Ajuria, E. B. (2017). An Experience of the Application of Augmented Reality to Learn English in Infant Education. 2017 International Symposium on Computers in Education (SIIE) (pp. 1-6). Lisbon. doi:10.1109/SIIE.2017.8259645

Ministry of Education. (2013). Malaysia Education Blueprint 2013-2025. Malaysia: Author. Munn, Z., Peters, M. D. J., Stern, C., Tufanaru, C., McArthur, A., \& Aromataris, E. (2018). Systematic review or scoping review? Guidance for authors when choosing between a systematic or scoping review approach. BMC Medical Research Methodology, 18(1). 
INTERNATIONAL JOURNAL OF ACADEMIC RESEARCH IN PROGRESSIVE EDUCATION AND DEVELOPMENT

Vol. 10, No. 2, 2021, E-ISSN: 2226-6348 @ 2021 HRMARS

doi:10.1186/s12874-018-0611-x

Penprase, B. E. (2018). The fourth industrial revolution and higher education. Higher education in the era of the fourth industrial revolution, 207-229.

Redondo, B., Cózar-Gutiérrez, R., González-Calero, J. A., \& Sánchez Ruiz, R. (2019). Integration of Augmented Reality in the Teaching of English as a Foreign Language in Early Childhood Education. Early Childhood Education Journal. doi:10.1007/s10643-019-00999-5

Richardson, D. (2016). Exploring the Potential of a Location Based Augmented Reality Game for Language Learning. International Journal of Game-Based Learning, 6(3), 34-49. doi:10.4018/ijgbl.2016070103

Sadikin, I. S., \& Martyani, E. (2020). Integrating Augmented Reality (AR) In EFL Class For Teaching Vocabulary. PROJECT (Professional Journal of English Education), 3(2), 161167. https://doi.org/10.22460/project.v3i2.p161-167

Safar, A. H. (2016). The Effectiveness of Using Augmented Reality Apps in Teaching the English Alphabet to Kindergarten Children: A Case Study in the State of Kuwait. EURASIA Journal of Mathematics, Science and Technology Education, 13(1). doi:10.12973/eurasia.2017.00624a

Siddaway, A. P., Wood, A. M., \& Hedges, L. V. (2019). How to do a Systematic Review: A Best Practice Guide to Conducting and Reporting Narrative Reviews, Meta-analyses and metasyntheses. Annual Review of Psychology, 70.

Sirakaya, M., \& Sirakaya, A. D. (2018). Trends in Educational Augmented Reality Studies: A Systematic Review. Malaysian Online Journal of Educational Technology, 6(2), 60-74. https://doi.org/10.17220/mojet.2018.02.005

Solak, E., \& Cakır, R. (2017). Investigating the Role of Augmented Reality Technology in the Language Classroom / Istraživanje uloge tehnologije proširene stvarnosti u nastavi jezika. Croatian Journal of Education - Hrvatski Časopis Za Odgoj i Obrazovanje, 18(4), 1067-1085. https://doi.org/10.15516/cje.v18i4.1729

Soo, K. Y., Syed Ahmad, T. S. A., \& Hasan, N. H. (2019). EXPLORING THE POTENTIAL OF AUGMENTED REALITY IN ENGLISH FOR REPORT WRITING: A PERCEPTIVE OVERVIEW. International Journal of Education, Psychology and Counseling, 4(33), 13-21. https://doi.org/10.35631/ijepc.433002

Spiteri, M., \& Rundgren, C. S. N. (2018). Literature Review on the Factors Affecting Primary Teachers' Use of Digital Technology. Technology, Knowledge and Learning, 25(1), 115128. https://doi.org/10.1007/s10758-018-9376-x

Taskiran, A. (2018). The effect of augmented reality games on English as foreign language motivation. E-Learning and Digital Media, 16(2), 122-135. doi:10.1177/2042753018817541

Tobar-Muñoz, H., Baldiris, S., \& Fabregat, R. (2017). Augmented Reality Game-Based Learning: Enriching Students' Experience During Reading Comprehension Activities. Journal of Educational Computing Research, 55(7), 901-936. doi:10.1177/0735633116689789 
INTERNATIONAL JOURNAL OF ACADEMIC RESEARCH IN PROGRESSIVE EDUCATION AND DEVELOPMENT

Vol. 10, No. 2, 2021, E-ISSN: 2226-6348 @ 2021 HRMARS

Tsai, C. C. (2018). A Comparison of EFL Elementary School Learners' Vocabulary Efficiency by Using Flashcards and Augmented Reality in Taiwan. The New Educational Review, 51(1), 53-65. https://doi.org/10.15804/tner.2018.51.1.04

Vlahov, D. (2017). Book review: Brigid Freeman, Simon Marginson i Russell Tytler: The Age of STEM. Drustvena Istrazivanja, 26(2), 303-307. https://doi.org/10.5559/di.26.2.11

Wang, Y.-H. (2017). Exploring the effectiveness of integrating augmented reality-based materials to support writing activities. Computers \& Education, 113, 162-176. doi:10.1016/j.compedu.2017.04.013

Wang, M., Callaghan, V., Bernhardt, J., White, K., \& Peña-Rios, A. (2017). Augmented reality in education and training: pedagogical approaches and illustrative case studies. Journal of Ambient Intelligence and Humanized Computing. doi:10.1007/s12652-0170547-8

Yaacob, A., Zaludin, F., Aziz, N., Ahmad, N., Othman, N., \& Fakhruddin, M. R. (2020). AUGMENTED REALITY (AR) FLASHCARDS AS A TOOL TO IMPROVE RURAL LOW ABILITY STUDENTS' VOCABULARY. Practitioner Research, 1, 29-52. https://doi.org/10.32890/pr2019.1.0.8182.

Yes, H. -C., \& Tseng, S. S. (2020). Enhancing Multimodal Literacy using Augmented Reality. Language Learning \& Technology, 24(1), 27-37. https://doi.org/10125/44706.

Yunus, M. M. (2018). INNOVATION IN EDUCATION AND LANGUAGE LEARNING IN 21ST CENTURY. Journal of Sustainable Development Education and Research, 2(1), 33-34. https://doi.org/10.17509/jsder.v2i1.12355 